\title{
Normative theories of journalism in Russia: stage of origin
}

\section{Teorias normativas do jornalismo na Rússia: estado de origem}

\author{
Sergey G. Korkonosenko
}

Professor and Chair, Department of the Theory of Journalism and Mass Communications - Saint Petersburg State University. <s.korkonosenko@spbu.ru>

\section{ABSTRACT}

Normative theories of journalism are a classical object of research. In this area there are canonical approaches and schemes, which, however, are constantly subject to doubts and changes. Historical and theoretical study of the Russian experience provides an opportunity not only to see original interpretations of classical theme, but also offer non-traditional approaches to the classification of normative theories. The author analyzes the statements and practices of the outstanding Russian writers, journalists and thinkers of the XVIII-XIX centuries, who were concerned about the role of the press in society. As a result, there appears the basis for identification of three types of normativity characteristic for Russian journalism in the past and present. Namely, they are: directive, professionaldeontological and professional-pragmatic types.

\begin{abstract}
RESUMO
Teorias normativas do jornalismo são um objeto clássico de pesquisa. Nesta área existem abordagens e esquemas canônicos, que, no entanto, estão constantemente sujeitos a dúvidas e mudanças. O estudo histórico e teórico da experiência russa oferece uma oportunidade não só para ver interpretações originais do tema clássico, mas também oferecer abordagens não-tradicionais para a classificação das teorias normativas. $\mathrm{O}$ autor analisa as declarações e as práticas dos excelentes escritores, jornalistas e pensadores russos dos séculos XVIII-XIX, que estavam preocupados com o papel da imprensa na sociedade. Como resultado, surge a base para a identificação de três tipos de características normatividade para o jornalismo russo no passado e no presente. Ou seja, eles são: directiva, profissional-deontológica ou profissional-pragmática.
\end{abstract}

Palavras-chave: Jornalismo. Teoria Normativa. Jornalismo Russo.

\section{Normativity as a characteristic of journalism theory}

In Russia, focused study of normative theories of journalism has become a developed research field. Like a number of other theoretical concepts, the concept of normativism entered the Russian lexicon from foreign sources and therefore has a clearly visible "foreign" color. However, this does not mean that it remains unfamiliar to Russian theoretical context; on the contrary, it is highly organic to Russian scientific tradition.

We are interested in understanding normativity as a special quality of the theory. It is associated with the ideal, which is projected on the practice as 
a standard of behavior, and thus it is distinguished from functionalism, which deals with the activity characteristics of a social object. According to one of the recognized sources:

Normative theories of journalism concern ideal functions of the press, what the press should do [...]. In principle, there are many normative theories of journalism as there are political systems [...]. Journalistic practice likewise does not always accord with normative theories of journalism, but these theories remain an important component of professional training (Benson, 2008, p. 2591-2592).

As McQuail argues:

Essentially, we are dealing with a range of ideas about the purposes and or consequences of journalism, often with a normative tendency expressed in prescriptions and assertions of how journalism ought optimally to be carried out [...]. At the same time, even in this summary form, they provide a rich mine of ideas about the purposes and potential significance of journalism in society (2008, p. 49-52).

We'd like to emphasize not so much the mention of the many theoretical directions (this fact is accepted a priori), but rather the recognition of the value of the internally diverse totality. In other words, if this or that concept cannot be accepted as universal norm, the coexistence of many developed theories should be considered as an absolute standard for the research field.

\section{Normative theories and professional ideologies}

Mean while at this point the need arises to get off the beaten Western research ersway. No matter how varied their classification decisions, while defining the historically first experience of the normative theories description, they invariably referred to the "Four theories of the press" by Siebert, Peterson and Schramm (1956). For example, Finnish researchers write that "Theories of the press" is a concept which since the classic Four Theories [...] has typically referred to the role which the mass media at large play in various societies, past and present" (Nordenstreng; Pietiläinen, 1999, p. 146). Certainly, this is a wrong choice of reference point, not only because the famous classification of American professors today looks very imperfect. The Finnish authors indicate 
its apparent disagreement with the position of mass media in modern societies; they quote a radical statement of the British professor Sparks (1998):

Four Theories of the Press provides no insights whatsoever into the past, present or future of the media systems of post-communism [...]. It should be relegated forthwith to the gloomiest recesses of the Museum of the Cold War (Nordenstreng; Pietiläinen, 1999, p. 146).

But even more doubts are connected with a short historical period within which theoretical problems on the role of media were discussed. In the middle of the last century Siebert, Peterson and Schramm in the best case have intensified a scientific discourse on these issues, but in no way were its pioneers. In American literature one can easily find mentions of the much earlier periods of discussion, for example:

The hegemonic western model of journalism, which has dominated normative discussions for the past century, derives from a set of relationships and practices formed around relatively monopolistic daily newspapers and wire services at the end of the $19^{\text {th }}$ century. This model assumes that news organizations are relatively autonomous from the state and that individual journalists are independent agents (Nerone, 2013, p. 446).

There are reasons for saying that the normative content inherent in most (if not all) attempts to justify theoretically the roles of journalism and media in society. Speaking of normative theories, it should be borne in mind not their disciplinary affiliation, but the presence of ideal and intellectual design of the best image of the press; we have in mind more a "genre" of discussion than separate special discipline.

Although by tradition this quality are in demand primarily in the social view on journalism, relatively narrow, aspect theories also may have normative nature - for example, which define standards of the press language or ethics of the news gathering. A particularly powerful normative potential usually is included in the system modeling of media practice, when the "correct" approaches to social-political status of the press, its thematic content and structural organization, and forms of professional activities are being prescribed. Therefore, limitation only (or mainly) to the relationships of the press with the 
government and, accordingly, to the freedom of the press gives rise to simplified schemes, which quickly become obsolete with the changing political situation. From the theoretical-disciplinary point of view, this is a substitution of analysis of normativity on the study of the press in the light of political science in the context of political history. It seems that is the main source of alternating waves of denials and disagreements, which accompany the development of normative theories of journalism in the world.

In our opinion, this problem would be eliminated if to change the angle of view on the origin of normative theories. Instead of building different kinds of versions of the journalism's relations with the government, we propose to look at the coordinate system, in which the projects of "proper" journalism are being formed. Whether the ideal of the press was formed in the minds of the rulers and their official ideologists? Was it born in direct contact of press with current life? Or it was implemented from adjacent areas of scientific knowledge? That's what the perspective on normative theories is proposed as a primary one. Hardly it is possible to list and describe all existing theoretical approaches and systems of thinking. But hardly there is a necessity to establish such registries. Perhaps the greater effect will be gained due to revealing several types of normativity, based on different grounds.

As it seems, the Russian experience has created especially fertile ground for such analysis. The relative autonomy of the country, its culture and media from a more or less homogenous European community (with all the remarks on using foreign innovation and a constant eye to the West) gave space and even forced to find their own solutions of general interest issues. In particular, this relates to normative ideas about press, which, of course, appeared long before now canonized theoretical works.

For following analysis, the question of the dating of the origins of the normative-theoretical approach to the press is of fundamental importance. First, we would like to give a chronological depth to the study of the normative aspect of reflections on the place of journalism in society, in contrast to the ritual references to the 1950-ies. Second, in this context, the possibility to reconstruct national specific processes in the history of scientific thought appears, instead of reproducing the logic of the analysis, which was formed in the West and now became almost commonly accepted in our country. Thirdly, it would be incorrect way to use a straightforward approach to the object of study in which normative theories necessarily possess this name and are presented in the systematically developed conceptual schema. Truly: 
In most systems, different (sometimes even incompatible) elements from different theories coexist in interaction. What normative theory dominates, we have to judge by the conventions, assumptions, and components of the prevailing ideology, and sometimes also by decrees, laws and constitutional solutions (Bakulev, 2010, p. 18).

This means that normative theory may appear, for example, in the form of a common professional ideology and derived methods of editorial activity, alternative to the dominant models of practice that are based upon comprehensively designed publisher's or editor's credo, at last, even in the forms of views and declarations of professional principles which did not gain a support from the contemporaries. This is what the modern Norwegian researcher talks on:

\footnotetext{
Journalism's ideology can be summarised as the content of the argument that the profession is important in a political, social and cultural sense - that we need journalism. This ideological argumentation can be found everywhere in what journalists do, in the practices of the news institution and in the encounters between media professionals and their surroundings (Sjøvaag, 2013, p. 135).
}

The author expressly solidarities with a certain ideology, it is also a normative theory of the press: "The professional ideology of the press is rooted in the fact that news is not only a public service but that it is also, and perhaps primarily, a business. This makes journalistic ideology highly compatible with the dominant ideology" (Sjøvaag, 2013, p. 143). In many Western countries, these ideological and theoretical principals have been adopted at the level of common sense, or common standard of thinking. Nota bene: we demonstrate the presence of a certain normative professional ideology, but not its universal acceptability in all regions of the world.

Taking into account the above methodological assumptions, let's move on to the analysis of the origin of normative theories in the history of Russian society and journalism. We will focus on the eighteenth and nineteenth centuries. It's clear that at the early stages of a science development there were not theories as such, but only their preconditions and initial manifestations. Nevertheless, without such data it is impossible to clarify the problem of national schools dealing with the theory of journalism, in particular its normative sector. Our point is that journalism theory is subject to the general law of scientific 
knowledge formulated in Imre Lakatos's well-known saying (though made on another occasion): "Philosophy of science without history of science is empty; history of science without philosophy of science is blind" (1971, p. 91). This formula relates to the general laws of epistemology: studying theories on "horizontal" time plane makes no sense if we do not attempt to see their genesis and past development.

\title{
Directive type of normativity
}

Parallels between, on the one hand, theory and, on the other hand, current experience of the press, common sense of professionals and the public are possible only to a certain limit. Further either the replacement of theoretical work on other types of activities begins, or a total denial of the essence of the journalism studies. The events from the Russian journalism history are pushing the researchers to this wrong way of reasoning. So, the Russian historian of press makes a very categorical statement:

The authorities' thought on journalism, which was not usually mentioned by researchers, was a practical one and was written down mostly in legal documents and recommendations. In this respect, the experience of the Russian Empress Catherine II (1762-1796) is significant (Zhirkov, 2011, p. 178).

After that he analyzes the official documents of the supreme authorities dealing with press, and makes a general conclusion:

\begin{abstract}
Under various conditions, every ruler of the country looked for ways to handle freedom of the press and found the best solution in those documents. Actually, that practice reflected a very significant moment in the development of thought, i.e. the implementation of the need to manage a huge state cannot always wait for corresponding theoretical treatises to be developed. This conclusion can be applied to later periods of Russian history (Zhirkov, 2011, p. 178).
\end{abstract}

Theorists should not be offended by such a skeptical evaluation of their contribution. Disagreements between representatives of certain disciplines and sub-disciplines can be perceived as a fact of scientific polemics, not more, they give new impetus for searching the truth. In a similar polemical collision, 
the Brazilian theorist insists that "journalism makes possible the establishment of a specialized field of knowledge which [...] requires the development of its own, specific methodologies in order to be fully understood" (Machado, 2005, p. 12). In our case, when the priority in building the conceptual foundations of Russian journalism is given to the official authorities there is a need to assess the theoretical importance of the historian's point of view. First of all, there is no reason not to trust the facts presented by a qualified author. But what kind of normativity the top-down directives do contain? From ideological viewpoint, they merge with the representations on the press, which for decades called authoritarian. Can we fully attribute these views with the category of theories or not? Without a long explanation it is clear that administrative solutions of practical tasks often have little in common with intellectual search, although they do not exclude it absolutely.

This consideration is well illustrated by the history of the press legislation. Researchers of the press has long recognized that the first newspaper appeared in Russia due to the powerful will of Peter the Great; his Decree on this matter on Dec 15, 1702 in fact put beginning of legal providing for the producing of periodicals (Talovov, 1994, p. 23). However, this does not mean that after that was formed and developed an independent branch of law, namely the law on the press. According to one of the leading Russian experts in the field of information law: "legislation on mass media traditionally developed in Russia primarily as 'censorship legislation'"' (Fedotov, 1999, p. 298). This statement is provable based on the documents. In fact, the author identifies the type of normativity inherent in official acts:

Until June 12, 1990 [adoption of the Soviet Law "On press and other mass media". - Author [...] there were norms relating to separate issues of the periodical press, radio and television, but there were no interconnections between them in general, they did not form an integral mechanism of legal regulation. The lack of legal regulation was compensated by the [Communist] party rules (Fedotov, 1999, p. 297).

It was said about the Soviet time. But we tend to extend this assessment on the pre-revolutionary practice of regulation. Historians of the press offer analytical observations on autocracy's attempts to ease the burden of censorship: 
In the legislation for the supervision of the press in 1840-1860-ies there is a trend. At certain points, the supreme power puts forward or supports the drafting of a new censorship Statute. However, as soon as it comes to its approval, it begins to doubt in the expediency of such change [...]. Probably, the reason is that well-developed Statute of 1828 as a whole is consistent with the conditions of preventive censorship. While it remains, albeit in limited sizes, a fundamentally new Statute cannot appear (Makushin, 2008, p. 309-310).

This refers to the conservation of administrative control with the adoption of a liberal, on formal grounds, law on press in the reign of Alexander II. Regarding the law, legal commentators unanimously accentuated the liberal idea of limiting administrative arbitrariness in the press field. However, due to the specificity of legal discourse, they tried to build not so much the ideal of journalism, how desirable resolution procedure for arising collisions. Moreover, the focus of the authors was not the whole complex of problems of the press social functioning, but primarily a matter of the press freedom. Eugenie Prokhorov in detail examined views of the Russian liberal jurists on the issue of press freedom using works by Vasily Bervi-Flerovsky (Freedom of speech, tolerance, and our laws on the press, 1872), Alexander Gradovsky (Freedom of the Russian press, 1905) and Konstantin Arseniev (The legislation on the press, 1903). On the conclusion of the researcher:

They proceeded from the idea of strengthening the Russian state, without fundamental changes in the nature of governance [...]. In the process of 'normal' development of the Russian state and society, the press [...] should play a crucial role by serving to education of the people, actively interact with public opinion, openly discuss practical issues of life and to struggle against everything that hinders the development of the country (From the desktop, 2013, p. 34).

But even so loyal to the government amendments to the existing order of things in very small part were embodied in official documents and, accordingly, did not play decisive role for own time.

Thus, normativity as a holistic view of journalism directly related to the authorities' policies, which, in turn, can be attributed neither to the categories of political science nor legal theory in the proper sense of the word. There is no reason to consider them a part of the theory of journalism, in true sense. Precisely, this type of normative conceptions should be called directive one 
because the power creates norms and introduces them into practical activities in administrative order.

\section{Professional-deontological type of normativity}

Attempts to reduce intellectual modeling of press in the "old" Russia only to the adoption of authoritative decisions seem hasty and unproductive. It is impossible to deny many examples of reflections on the purpose of the public speech and the mission of the journalist and, therefore, statements of theoretical problems, at least at the initial level. It should be recognized in a science, just as it was recognized the formation of a distinctive tradition of empirical researches in the field of press which originated not in the twentieth century and not trough "importing" from the West. For example, according to Alexander Akopov,

The origins of sociological methods should be searched in the first Russian periodicals of the XVIII century. Particular significance had "Proceedings [Trudi] of the 'Free economic society"' - a monthly magazine established in 1765 in St. Petersburg and mainly devoted to agricultural problematics. In the first issue of the magazine a questionnaire was included entitled "Economic questions relating to agriculture from the differences of the provinces" (2002, p. 201-204).

Surveys tradition was preserved for the whole period of the magazine existence (until the beginning of XX century). Other scientific and historical investigations show that in the XIX century Nikolay Dobrolyubov became a pioneer in the use of quantitative and qualitative study of periodicals (now this method known as content analysis) and Nikolay Chernyshevsky began to apply statistics to the study of reader's mail, etc (Talovov, 1993).

However, to identify elements of a normative knowledge about press in the history of thoughts is more difficult task than to find the facts of empirical experiments. As a rule, such elements are dissolved in other theoretical approaches: philosophical, political, sociological, etc. Therefore, there is a danger of either retelling of well-known information (names, works, quotations), or repetition of the data from the history of other disciplines related to journalism. To avoid such a danger, we'll come to the solution from the typological dimension of normative views and statements. Actually, we have already chosen this way when above we defined the directive type of normativity.

In this light, how to estimate the majestic figure of Mikhail Lomonosov and his views, expressed in his famous "Discourse on the responsibilities of 
journalists in presenting their works, intended to maintain the philosophy of freedom" (Rassuzhdenie ob obiazannostiakh zhurnalistov...)? Whether we can perceive the paper as a set of ethical standards, as it is often done, especially when the author names his proposals "The rules"? "Anyone who takes the trouble to inform the public [...] should first weigh his own possibilities"; "You must banish from your mind every prejudice"; "Journalist should not hurry to condemn hypotheses"; "Never allow yourself too high idea of their superiority". In fact, these lines look like the "Prescription handbook" for the press employee. But if we consider these conceptual ideas in the coordinates of all the Lomonosov's selfless activities on the good of the Fatherland, culture and science, their deep background will open. The evidence of the contemporary, who has precisely identified the system of ideals of the Russian genius, will help us. Publisher, writer and educator Nikolay Novikov wrote: "This man was of great intelligence, high spirit, and profound knowledge" (Novikov, 2011, p. 46). Surely, these "applied" rules for journalists were dictated by the belief in the beneficence of the hard work of the mind, spirituality and honest knowledge of the truth.

Whether it is not the quintessence of the ideal of journalism? The ideal as a model and a mandatory rule is the essence of normative theory. But the ideal also determines the direction of reasoning in professional deontology - as moral imperative which is consciously accepted by the journalist. In this case, these two theoretical spaces coincide. In contrast to most common logic of normativism, in which the starting point is the relations of the press to the government and the socium, the personal self-determination of the journalist comes to the fore. Let's risk saying that we meet a professional-deontological type of normative understanding of journalism.

Professional-deontological type of normativity is highly organic to Russian journalism; it was being reproduced in judgments on the press of prominent national journalists, as well as, of course, in their practice. From ideological positions, the great Russian writers of the XVIII-XIX centuries largely differ from each other. But in their statements about the mission of the public literature the moral motives of personal ministry and calling exist like a dominant, even in creations of the most politicized authors. On what grounds Nikolay Dobrolyubov appreciates the writings of Mikhail Saltykov-Shchedrin?

The mass of the people [...] will always speak the name of Shchedrin with respect and gratitude: he loves this people, he sees many good, noble, although not developed or mis-directed instincts in these humble, simple-minded workers (1900, p. 362). 
What the mission chose Alexander Herzen during the 1860's, when in some European states anti-Russian campaign was widely developed? On the conclusion of modern historians, Herzen

considered his duty to speak on behalf of the country and the Russian people, telling how sprouted in Russia the stirrings of a democratic movement, how the Russian society managed to consolidate itself in the liberation of peasants and what the role the government and the Russian press have played (Gromova, 2012, p. 206).

What is the legacy of the national press wanted to preserve the writers in front of the onslaught of commercialization at the turn of XIX and XX centuries? The liberalist Lyudvig Slonimsky stated:

In our country, newspaper and magazine publishing is not a field for profitable investment, but for selfless public service [...]. Firmly established traditions of Russian journalism give a hope that it will never be given a priority to purely commercial and capitalist spirit, and that, freed from external oppression, the press will not fall under another yoke, even worse one, which poisons its spiritual essence, its soul $(2001$, p. 178, 181).

There is a plenty of examples of this kind, which as though accomplish deontological perspective in understanding social functioning of the press. Journalism as space and chance of moral choice, and even a personal feat - is not just typical of Russia in its past. Such understanding of the role of media (it is no exaggeration to say - theoretical understanding) has had a powerful impact on the organization and methods of everyday editorial practices. Most fully this influence resulted in the formation of traditions and experience of Russian publicism [publicistica] as unique in a world journalism phenomenon. The phenomenon of publicism, with its openly represented identity of the author is in opposition to the normative standards of the Western press. The author's publicism does not coincide with widely accepted interpretations of journalism as primarily informational phenomena, as media etc. Respectively, it does not correspond with the normative canons of so-called objectivity, detachment from the public topic of the day, and nominal separation of facts from 
opinions. It is clearly recognized by the European researchers who undertake comparing "abnormal" Russian (East European) model of press with a "normal" West European. Polish media analyst, Karol Jakubowicz, who gravitated to the Western school of journalism, but was well acquainted with cultural traditions of Eastern Europe, wrote in this connection:

[In Central and Eastern European countries journalists want to become a mouthpiece for the people]. That [...] is a reflection of the traditional role of the intelligentsia in Central and Eastern European countries. This results in a type of journalism that is conviction-driven. By subordinating their work to promoting social and political change, journalists must necessarily opt for a partisan, advocacy-oriented and campaigning style of writing, bordering at times on propaganda (2001, p. 75).

Apparently, for supporters of strict standards of professional work emanating from the strictly formalized normative theories will seem excessive arguments concerning the journalist's creative freedom in choosing ways of activity. Meanwhile, just so modern Russian researchers consider correlation of rules and freedom:

Rules and regulations, under which journalist operates [...] are specific - probabilistic and variable. Once disappear the understanding of the flexibility of norms and rules and they are associated with certain templates, creative nature of the profession fades [...] these norms and rules, being internalized thoughtlessly and uncritically, may lead to impersonality of the journalist and standardization of his texts (Gorohov; Dzyaloshinsky, 2012).

We tend to see in this way of reasoning about journalistic methods a direct connection with Russian professional and deontological traditions in the normative understanding of journalism. Such a connection will be visible in a frame of any responsible approach to studying continuation of public service tradition in the national press.

\section{Professional-pragmatic type of normativity}

It would be wrong and unfair to limit the range of normative views in Russian journalism only by the above directions. Russia could not ignore the 
processes that were developing in neighboring states, primarily in Europe. Accordingly, typical for Europeans professional-pragmatic type of normativity in journalism was bound to find its adherents in our country. Understanding newspaper and magazine business as a highly developed industry which produces high-quality products and gains a success in the goods market was caused by the objective history. In this respect, Russian experience hardly bears a fundamental difference from the West. However it began to be formed later and under the strong influence of foreign experience and views on press. As historians stated, the slogan of press freedom

in its bourgeois interpretation the Russian entrepreneurs from journalism [...] have put forward relatively late [...] such representatives of the Russian bourgeoisie as Trubnikov, Kraevskiy and others, began to use the slogan 'freedom of press' only in the second half of the XIX century and mostly in the official petitions, not in public speeches (Esin, 1981, p. 19).

Of course, this does not mean that the desire for economic profit was not typical for publishers in the eighteenth and nineteenth centuries or that there was no commercial success of these endeavors. They not only were gaining strength in newspaper and magazine industry, but also played a significant role in the improvement of professional techniques and skills. Otherwise would be contrary to the laws of business, which interests are pushing forward the quality of the product. According to experts, the success of publishers and editors

in many ways, had a revolutionary importance, as it contributed to the progress in journalism: the creation of a certain type of publication [...] the struggle for the improvement the role of journalism in the eyes of government and society, a development of the journalism profession, etc. (Zhirkov, 2007, p. 7).

However, entrepreneurial motives did not dominate in the overall professional and ideological discourse, and their supporters caused, to put it mildly, an ambiguous attitude. For example, contemporary biographers of successful publisher and editor in the nineteenth century Andrey Kraevskiy stated that he"often was been described as literary profiteer, ruthless exploiter of writers who persecutes in his publishing activities exclusively financial interests" 
(Gromova, 2001, p. 6). Wary attitude to the commercial success intentions was characteristic for many prominent figures of journalism for a long time. In the beginning of XX century the publicist Sergey Krivenko claimed: "Capitalization of literature possesses many negative sides, so even the good things that were done provokes some kind of special doubt or directly shows a commercial stamp" (Krivenko, 2001, p. 145).

The bright embodiment the pragmatic professional ideology has gained in a publishing strategy and practice of Osip Senkovsky (1800-1858), who entered journalism under the pseudonym of Baron Brambeus. It is noteworthy that he was a great admirer of the English magazine press, as well as he had to endure the incomprehension of many of his contemporaries, bordering on hostility. However, it should be noted that "commercial stamp" was not the main attribute of his activities, while the clearly visible is a desire to succeed thanks to high level of the publishing production and establishing contacts and interaction with the audience.

Research works on Senkovsky's life and career in summarized form describe the ideal model of journalism, which he pursued in his journal "Library for Reading". In our opinion, the model is highly relevant to professionalpragmatic normativity in the field of press. This model, in brief, includes:

Educational program, i.e. providing information that expand mental and moral horizon of the reader; Responsibility of the journalist to the reader, the rejection of the abuse of his trust; Refusal of unfair competition; Taking into account the level of reader's knowledge; Concern about the comfort of the reading process that is nice and elegant design, care of the issues' timing, and so far (Sherbakova, 2005, p. 30-31).

However, it was brought to life on a Russian ground and served to development of the whole direction in national journalism which gained high popularity among readers. As experts noted, "Library for Reading" "became the perfect embodiment of the type of 'thick' encyclopedic journal, which operated in the Russian journalism for almost a century: from 1820-ies to the revolution of 1917" (Sherbakova, 2005, p. 222). As it seems, this evaluation has a parallel with an enlightening understanding of the mission of the press, so characteristic for the Russian tradition; in a wide range of manifestations it's introduced both in directive and in professional-deontological types of normative views on 
journalism. That's why we include this direction of professional ideology in a set of typical Russian phenomena.

\section{Conclusion}

The types of views on journalism, discussed above more or less detail, not in full coincide with the classifications of normative theories of the press proposed in Western literature, neither canonized nor relatively new. For example, it is difficult to draw direct parallels with the theories given in the Mc Quail's works: Liberal theory, Public interest theory, Communitarianism, Development journalism, Critical social theory (2008, p. 50-51). No doubt, some points of intersection in this or that case will be, but in no way they are the signs of identity. For example, the theory of public interest has similarities with the professional-deontological type, but the first is configured mainly socially, whereas the latter, as emphasized above, contains an explicit moral determinants. Conservative and statist ideologies (for instance, in the case of the editor of the conservative newspaper "Moskovskie Vedomosti", Mikhail Katkov, the late XIX) only on the ultimate level of abstraction may overlap with journalism for development or the authoritarian theory, and so on. Thus, the conclusion of the Finnish journalism analyst should be regarded true when he believes that "the Russian media system is unique in its historical development ". But the continuation of the statement: "Its contemporary character is no longer so special but rather a more or less typical case for highlighting universal problems" (Nordenstreng, 2010, p. 186) - deserves further analysis and, possibly, critical rethinking.

\section{REFERENCES}

AKOPOV, A. First sociological research in the Russian journalism. In: Akopov, A. Some questions of journalism: history, theory, practice (articles of different years). Rostov-on-Don: Tura; Gefest, p. 201-207, 2002.

BAKULEV, G. Mass communication: Westernn theories and concepts. Moscow: Aspect Press, 2010.

BENSON, R. Journalism: normative theories. In: DOSBACH, W. (Ed.). The international encyclopedia of communication, v. VI. Malden, MA: Blackwell Pub., p. 25912597, 2008.

DOBROLYUBOV, N. Provincial Sketches of Shchedrin. In: Essays by N.A. Dobrolyubov. v. 1. St. Petersburg: P. P. Soikin Pub., p. 341-364, 1900.

ESIN, B. Russian newspaper and the newspaper business in Russia. Moscow: 
Lomonosov Moscow State University, 1981.

FEDOTOV, M. Positive mass information law. In: RIHTER, A. (Ed.). Legislation of the Russian Federation on mass media. Moscow: Center "Pravo i SMI", p. 295-540, 1999.

From the desktop of E. P. Prokhorov. In: PROKHOROVA, I. (Ed.).The book in memory of Professor E. P. Prokhorov: Scientific articles. Memories. Moscow: Lomonosov Moscow State University, p. 27-58, 2013.

GOROHOV, V.; DZYALOSHINSKY. Mass media: creativity and institutes. Mediascope, n. 4, 2012. Available in: <http://www.mediascope.ru/node/1219>. Access: 25 July. 2016.

GROMOVA, L. A. A. Krajewski - editor and publisher. St. Petersburg: St. Petersburg State University, Pub., 2001.

. Russian voice "from the other side". In: KORKONOSENKO, S. (Ed.). Media in the modern world. St. Petersburg readings. St. Petersburg: Philological faculty, St. Petersburg State University, p. 202-206, 2012.

JAKUBOWICZ, K. Rude awakening: social and media change in Central and Eastern Europe. The Public, v. 8, n. 4, p. 59-80, 2001.

KRIVENKO, S. Newspaper business and newspaper people. In: ESIN, B.; MAHONINA, S. (Eds.). Selected pages of Russian journalism of the beginning of XX century. Moscow: CheRo, p. 141-146, 2001.

LAKATOS, I. History of science and its rational reconstruction. In: COHEN, R.; BUCK, R. (Eds.). Boston Studies in the Philosophy of Science, n. 8, p. 174-182, 1971.

MACHADO, E. From journalism studies to journalism theories. Brazilian Journalism Research, v. 1, n. 1, Semester 1, p. 11-23, 2005.

MAKUSHIN, L. Censors hip regime and the system of the Russian periodical press in the era of the great reforms of Alexander II. 2010. 492 p. Thesis (PhD in Philology) - Faculty of Journalism, St. Petersburg State University, St. Petersburg, 2010.

MCQUAIL, D. Journalism as a public occupation: alternative Images. In: CARPENTIER, N.; PRUULMANN-VENGERFELDT, P.; NORDENSTRENG, K. et al. (Eds.). Democracy, journalism and technology: new developments in an enlarged Europe: the Intellectual work of ECREA's 2008 European media and communication doctoral summer school. Tartu: Tartu University Press, p. 47-59, 2008.

NERONE, J. The historical roots of the normative model of journalism. Journalism, $v$. 14, n. 4, p. 446-458, May. 2013. 
NORDENSTRENG, K. The Russian media system: something special? In: VARTANOVA, E. (Ed.). Content, channels and audiences in the New Millenium: interaction and interrelations. Moscow: Faculty of Journalism, Lomonosov Moscow State University, p. 183-186, 2010.

NORDENSTRENG, K.; PIETILÄINEN, J. Normative theories of the media: lessons from Russia. In: ZASSOURSKY, YA. N.;VARTANOVA, E. (Eds.). Media, communications and the open society. Moscow: Faculty of Journalism/Publisher IKAR, p. 146$159,1999$.

NOVIKOV, N. Experience of historical dictionary of Russian writers (excerpt). In: PIROZHKOVA, T. (Introd. article, comments, and notes). In the temple of memory. Literary-critical works of M. V. Lomonosov 1765-1865. Moscow: Lomonosov Moscow State University, p. 43-50, 2011.

SHERBAKOVA, G. Journal of O. I. Senkovsky “Library for Reading" (1834-1856) and formationof mass journalismin Russia. St. Petersburg: St. Petersburg State University Pub., 2005.

SJØVAAG, $H$. The meaning and function of journalistic ideology. In: TRIVUNDŽA, I.; CARPENTIER, N.; NIEMINEN, $\mathrm{H}_{\text {.; }}$ et al. (Eds.). Past, future and change: contemporary analysis of evolving media scapes. Ljubljana: Faculty of Social Sciences, University of Ljubljana Press: Založba FDV, p. 131-145, 2013.

SLONIMSKY, L. Periodical press and capitalism. In: ESIN, B.; MAHONINA, S. (Eds.). Selected pages of Russian journalism of the beginning of XX century. Moscow: CheRo, p. 175-181, 2001.

TALOVOV, V. Origins of sociological journalistic studies in Russia. Vestnik Moskovskogo Universiteta. Series 10, Journalism, n. 5, p. 27-35, 1993.

. The legislation of the Russian Federation on mass media and journalism. In: KORKONOSENKO, S. (Ed.) Social functioning of journalism. St. Petersburg: Chas Pik, p. 23-43, 1994.

ZHIRKOV, G. Interaction between journalism and journalism theory in Russia: from the $18^{\text {th }}$ to the Early $20^{\text {th }}$ Century. Russian Journal of Communication, v. 4, n. 3/4, p. 177-197, Summer/Fall, 2011.

Journalism: historical studes and portraits. St. Petersburg: Roza Mira, 2007.

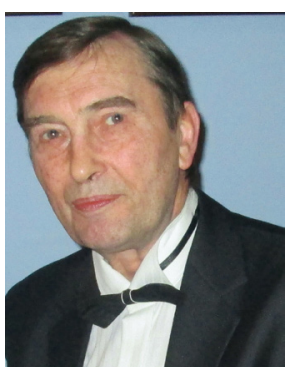

Recebido em: 29/7/2016

Aceito em: 29/7/2016

Endereço do autor:

Sergey G. Korkonosenko <s.korkonosenko@spbu.ru>

School of Journalism and Mass Communications

Saint Petesburg State University

1 Line, 26

St. Petersburg - 199004 - Russia 